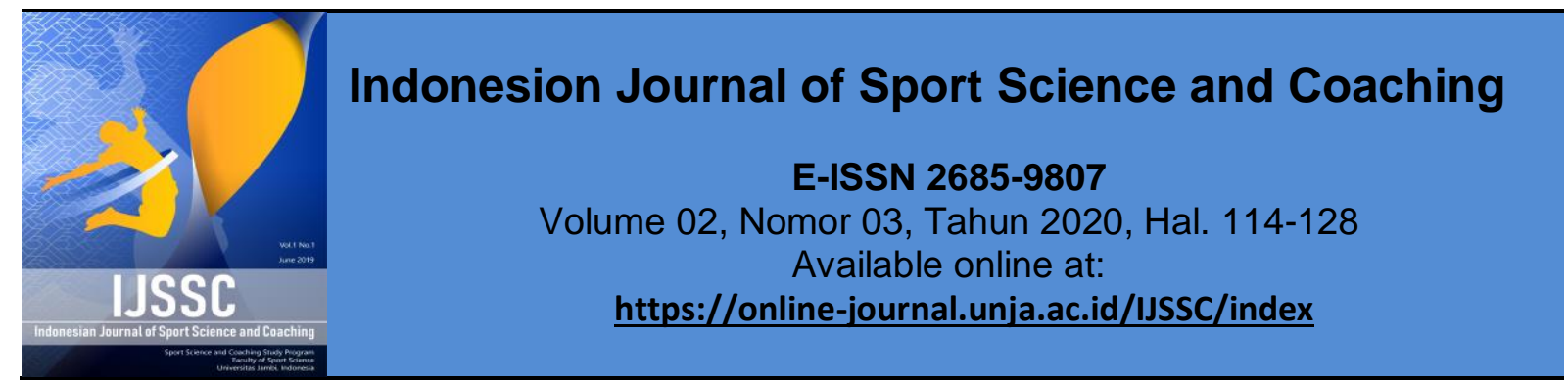

Research Article

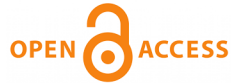

\title{
Meningkatkan Kemampuan Spike dengan latihan Skiping dalam Permainan Bola Voli di SD N 197/IX Pematang Gajah
}

\author{
(Increase Spike Ability with Skiping in Volyball Games in SDN 197/IX Pematang Gajah) \\ Yeni Sefiantri \\ SDN 197/IX Pematang Gajah \\ Kec. Jaluko,Kab.Muaro Jambi-Jambi-Indonesia \\ *Corresponding author: andrewsona1993@gmail.com
}

\begin{tabular}{|c|c|}
\hline Informasi Artikel & ABSTRACT \\
\hline $\begin{array}{l}\text { Submit: } 18-09-2020 \\
\text { Diterima: } 28-10-2020 \\
\text { Dipublikasikan: } 08-11-2020\end{array}$ & $\begin{array}{l}\text { The purpose of this study was to determine whether skiping } \\
\text { training can improve the ability to do spikes in volleyball games in } \\
\text { class VI SD Negeri } 197 \text { I IX Pematang Gajah. The research } \\
\text { method uses classroom action research. The results of the study } \\
\text { of skiping exercises can improve spike ability. The conclusion that } \\
\text { can be drawn in this classroom action research is that using } \\
\text { skiping exercises can improve the ability to do spikes in volleyball. } \\
\text { Keywords: skiping exercises, spike skills, volleyball }\end{array}$ \\
\hline Penerbit & ABSTRAK \\
\hline $\begin{array}{l}\text { Jurusan Pendidikan Olah Raga dan } \\
\text { Kepelatihan FKIP Universitas Jambi } \\
\text { Jambi- Indonesia }\end{array}$ & $\begin{array}{l}\text { Tujuan penelitian ini adalah untuk mengetahui apakah latihan } \\
\text { skiping dapat meningkatkan kemampuan melakukan spike dalam } \\
\text { permainan bola voly pada siswa kelas VI SD Negeri 197/IX } \\
\text { Pematang Gajah. Metode penelitian menggunakan penelitian } \\
\text { tindakan kelas. Hasil penelitian latihan skiping dapat } \\
\text { meningkatkan kemampuan spike. Kesimpulan yang dapat diambil } \\
\text { dalam penelitian tindakan kelas ini adalah dengan menggunakan } \\
\text { latihan skiping dapat meningkatkan kemampuan melakukan spike } \\
\text { dalam permainan bola voly. } \\
\text { Kata kunci: latihan skiping, kemampuan spike, bola voly }\end{array}$ \\
\hline
\end{tabular}

This Indonesian Journal of Sport Science and Coaching is licensed under a CC BY-NC-SA (Creative Commons Attribution-ShareAlike 4.0 International License)

\section{PENDAHULUAN}

Salah satu tujuan dari pendidikan jasmani di lembaga-lembaga pendidikan diantaranya ialah untuk meningkatkan kemampuan siswa melalui aktivitas jasmani yang diaplikasikan melalui cabang-cabang olahraga yang sudah memasyarakat di lingkungan suatu lembaga pendidikan atau sekolah yang bersangkutan (Hanief \& Sugito, 2015; Syarif, 2018; Wibowo \& Indrayana, 2019). Dan pada kenyataan masyarakat sangat banyak mengharapkan peningkatan kemampuan peserta didik terutama dalam cabang olahraga. 
Cabang olahraga permainan bola voli merupakan suatu cabang olahraga yang sangat memasyarakat, oleh karena itu peningkatan keterampilan bermain bola voli para siswa di suatu sekolah sudah merupakan suatu keharusan setelah melihat tuntutan yang sangat besar dari masyarakat. Bola voli adalah olahraga yang dimainkan oleh dua tim dalam lapangan dengan dipisahkan oleh sebuah net. Terdapat versi yang berbeda untuk digunakan pada keadaan yang khusus dimana pada akhirnya adalah untuk menyebar luaskan kemahiran bermain kepada setiap orang (PP. PBVSI, 2001).

Permainan bola voli merupakan cabang olahraga beregu yang melibatkan banyak orang yang sudah menguasai teknik permainan bola voli, baik individu maupun beregu. Teknik dasar bemain bola voli yang harus dikuasai yaitu 1. Servis, 2. Passing, 3. Smes (spike), 4. Blok. Berdasarkan pengamatan di lapangan teknik dasar untuk mempertahankan supaya permainan dapat terus berlangsung dan untuk membangun suatu serangan adalah teknik passing, dalam hal ini adalah teknik passing bawah.

Teknik dasar permainan bola voli menurut Amung Ma'mun dan Toto Subroto (2001:51) adalah servis, fungsinya untuk mengawali permainan ; passing, fungsinya untuk menerima atau memainkan bola yang datang dari daerah lawan atau teman seregu ; umpan, fungsinya untuk menyajikan bola ke teman seregu dengan keinginannya sehingga teman seregu tersebut dapat melakukan serangan ke daerah lawan sehingga bola yang akan disebrangkan ke daerah lawan tersebut dapat mematikan minimal menyulitkan lawan dalam memainkan bola dengan sempurna; bendungan atau blok fungsinya untuk menghadang serangan lawan dari dekatjaring sekaligus sebagai serangan baik ke pihak lawan agar bola menyentuh lantai. Unsur kondisi fisik yang dimiliki permainan bola voli adalah kekuatan, kelentukan, kelincahan, kecepatan dan daya tahan. Berdasarkan karakteristik tersebut, maka permainan bola voli harus melatih komponen itu, tentunya melalui proses latihan, dimana tujuan latihan adalah membantu pemain meningkatkan keterampilan dan potensi yang semaksimal mungkin.

SD Negeri 197/IX Pematang Gajahmerupakan sekolah yang memiliki pemain bola voli yang dapat dikatakan belum mahir dalam bemain bola voli, masih banyaknya terdapat kondisis fisik pemain yang lemah, lemahnya kekuatan otot khususnya kekuatan otot tungkai. Hal ini terlihat pada waktu siswa melakukan lompatan pada waktu melakukan pukulan atau smes, kurangnya pencapian prestasi yang didapat dalam pertandingan, yang semuanya tidak terlepas dari perhatian dan perang penting dari seorang guru atau pelatih.

Guru yang profesionaladalah guru yang benar-benar yang mempersiapkan pengajarannya dengan baik sebelum melakukan pengajaran atau pelatihan. Hal ini seyogyanya dimiliki dan diperhatikan oleh setiap guru di SDN 197/IX Pematang Gajah. Keberhasilan belajar atau latihan pemain dapat dilihat dari hasil latihannya, didalam proses belajar mengajar atau latihan pemain dikatakan berhasil apabila aktivitas dan hasil yang diperoleh pemain meningkat, selain itu yang menjadi permasalahan pemain ialah kurang aktif dalam proses pengajaran atau pelatihan. 
Dari hasil pengamatan dimana jumlah guru olahraga hanya satu orang dengan latar pendidikan penjaskes. Secara umum pemberian materi pelajaran penjas cenderung mengutamakan metode ceramah, kurangnya kontrol dari guru dalam proses pembelajaran, dan kurangnya penjelasan dari guru tentang materi yang diberikan yang ditandai dengan setiap pembelajaran berlansung siswa lansung dibariskan, diabsen, sedikit pemanasan dan langsung bermain dan kadang-kadang tanpa pemanasan. Disamping itu kurangnya pelatihan yang diberikan kepada pemain terutama pada pemain bola voli. Salah satu solusi permasalahan tersebut dengan melakukan latihan skipping dalam permainan bola voli agar dapat meningkatkan kemampuan melakukan spike dan mencapai prestasi yang baik umumnya.

\section{METODE PENELITIAN}

Penelitian ini akan dilakukan pada siswa kelas VI SD Negeri 197/IX Pematang Gajah Kecamatan Jambi Luar Kota Kabupaten Muaro Jambi yang berjumlah 11 orang semuanya siswa laki-laki. Siswa ini memiliki bentuk pisik yang berbeda, ada yang tinggi, ada yang sedang, dan ada yang pendek. Penelitian inidirencanakan pada bulan Januari 2019 dan Pebruari 2019 dilakukan dengan tiga siklus. Dimana siklus pertama dilakukan pada tanggal 18 dan 20 Januari 2019, Siklus kedua pada tanggal 15 dan 17 Pebruari 2019,Siklus ketiga pada tanggal dan 29 Februari 2019. Sedangkan tempat pelaksanaan penelitian dilakukan di kelas satu SD Negeri 197/IX Pematang Gajah

Prosedur ini akan dilakukan dalam tiga daur atau tiga siklus tindakan, satu kali siklus tindakan menggunakan dua kali tatap muka dalam waktu dua jam pelajaran (2 x 35 menit). Masing-masing siklus dalam penelitian tindakan di kelas ini dibagi dalam 4 (empat) tahap kegiatan, empat tahap kegiatan dimaksud adalah (1) Perencanaan, (2) Pelaksanaan, (3) Observasi dan (4) Analisis dan Refleksi

\section{Teknik Analisa Data}

Pada tahap ini dilakukan beberapa langkah yaitu : reduksi data, penyajian data, dan penarikan kesimpulan. (1) Reduksi data, Tahap ini merupakan proses pemilihan, pemusatan perhatian pada penyederhanaan, pengabstrakan, dan transformasi data kasar yang muncul dari catatan-catan tertulis di lapangan. Analisis ini dilakukan dengan cara mengumpulkan data berulang-ulang, lalu dianalisis dan kemudian pengumpulan data diulang kembali, lalu dianalisis lagi, begitu seterusnya sehingga mendapatkan hasil yang konsisten. (2) Penyajian data, Penyajian data dibatasi sebagai sekumpulan informasi tersusun yang memberi kemungkinan adanya penarikan kesimpulan dan pengambilan tindakan. Data yang diperoleh disajikan dalam bentuk kualitatif atau digambarkan melalui kata-kata. (3) Penarikan kesimpulan, Penarikan kesimpulan merupakan sebagian dari satu kegiatan dan konfigurasi yang utuh. Permulaan pengumpulan data, seseorang penganalisis kualitatif mulai mencari arti benda-benda, mencatat keteraturan, pola-pola, penjelasan, konfigurasi-konfigurasi yang mungkin, alur sebab akibat dan proposisi. 
Data yang dikumpulkan dalam penelitian ini melalui observasi, diskusi dan wawancara dengan teman sejawat, tes yang diambil dengan menggunakan format penilaian serta studi dokumentasi. Data penelitian disusun dan dirangkum untuk menemukan hal-hal inti yang sesuai dengan permasalahan penelitian secara sistematis dalam lembaran rangkuman sehingga lebih mudah mengolahnya. Selanjutnya membuat kesimpulan dan mengadakan pembuktian terhadap setiap kesimpulan yang dibuat sehingga diperoleh temuan-temuan yang dapat dipertanggungjawabkan.

Setelah data diperoleh, langkah selanjutnya adalah pengolahan data dengan cara : (1) Memeriksa hasil evaluasi siswa, (2) Memberikan penilaian dan (3) Menjumlahkan nilai keseluruhan siswa kemudian membagikannya dengan jumlah siswa.Adapun untuk menentukan keberhasilan siswa berdasarkan pengolahan data dengan menggunakan tehnik persentase penilaian, menurut (Nana dalam Wawang : 12).

Tabel 1. Tapsiran Persentase

\begin{tabular}{ccc}
\hline No. & Skala Nilai Keberhasilan & Predikat \\
\hline 1 & $80-100$ & Baik sekali \\
2 & $60-79$ & Baik \\
3 & $40-59$ & Cukup \\
4 & $20-39$ & Kurang \\
5 & $0-19$ & Kurang sekali \\
\hline
\end{tabular}

Untuk mengetahui keberhasilan suatu penelitian hendaknya dibuat kriteria keberhasilan itu sendiri. Untuk itu peneliti menetapkan kriteria keberhasilan dalam PTK yaitu jika nilai rata-rata siswa yang diukur melalui hasil tes mencapai nilai ratarata 70 dalam skala $10-100$, yang berarti tingkat penguasaan kompetensi minimal $70 \%$.

\section{HASIL DAN PEMBAHASAN}

Hasil Penelitian dari penelitian tindakan kelas yang dilakukan sebanyak 3 siklus. Dengan masing-masing siklus meliputi tahap perencanaan, pelaksanaan tindakan, observasi dan evaluasi dan tahap analisis dan refleksi.

\section{Hasil Penelitian Siklus I}

Penelitian siklus I dilaksanakan sebanyak dua kali pertemuan yaitu tanggal 18 dan 20 Januari 2019. Penelitian pada siklus I dibagi dalam 4 (empat) kegiatan yaitu : 1) Perencanaan, 2) Pelaksanaan tindakan, 3) Observasi dan evaluasi, dan 4) Analisis dan refleksi.

\section{Perencanan Tindakan Siklus I}

Tahap perencanaan tindakan pada siklus I meliputi kegiatan yang terdiri dari :

a) Menyusun Rencana Pelaksanaan Pembelajaran (RPP) 
b) Menyiapkan materi pembelajaran olahraga yaitu meningkatkan kemampuan spike dalam permainan bola volly dengan latihan skiping.

c) Menyiapkan semua sarana pendukung pembelajaran seperti;bola, beban, dan skiping.

d) Mempersiapkan format instrumen/ alat observasi yang akan digunakan pada saat proses pembelajaran berlangsung

e) Membuat alat evaluasi untuk mengetahui penguasaan materi pembelajaran dan untuk melihat hasil belajar.

\section{Pelaksanaan Tindakan Siklus I}

Di dalam melaksanakan pembelajaran dilakukan dua kali pertemuan dengan waktu 2 × 30' setiap pertemuan. Pada setiap pertemuan dilaksanakan evaluasi untuk mengetahui hasil belajar siswa setelah diberikan tindakan. Hasil penilaian tersebut dijadikan dasar bagi perbaikan-perbaikan kegiatan pembelajaran selanjutnya. Hal ini dilakukan untuk menunjang tercapainya siklus I dalam rangka peningkatan kemampuan spike anak untuk permainan bola volly yang menggunakan latihan skiping.

Pelaksanaan pembelajaran diawali dengan salam dan do'a, kemudian anak dibawa kelapangan bola volly. Pada awal pembelajaran siswa mengadakan pemanasan yaitu dengan melakukan gerakan tubuh bagian atas terlebih dahulu yaitu kepala. Kepala menoleh kekiri-kenanan, kepala dimiringkan kekiri-kekanan dan menundukkan kebawah dan keatas berulang kali. Berikutnya siswa menggerakkan badan bagian tengah yaitu pergelangan tangan yang diputar dan dirundukkan keatas dan kebawah, kemudian tangan direntangkan didepan dada dan dibuka berulangkali. Khusus tangan banyak variasi gerakan yang dapat dilakukan.Bagian pinggang diputar kekiri dan kekanan dan sebaliknya. Terakhir tubuh bagian bawah yaitu kaki dan pergelangan kaki.

Sesuai dengan program latihan pada siklus I para siswa melakukan skiping selama enam kali dimana setiap kali melakukan menggunakan waktu 4 menit. Setiap pelaksanaan skiping diberikan waktu istirahat dua menit. Setelah seluruh siswa melakukan skiping, guru membawa siswa untuk melakukan latihan spike (smas) secara bergantian. Tabel 2 menampilkan program latihan siklus I.

Tabel 2. Program Latihan Skiping Siklus I

\begin{tabular}{ccccccc}
\hline $\begin{array}{c}\text { Pertemuan } \\
\text { ke }\end{array}$ & Repitisi & Durasi & Intensitas & Set Latihan & Frekuensi & Bentuk \\
\hline I & $6 \mathrm{X}$ & 4 menit & $40 \%$ & 4 set & 1 kali & Skipping \\
\hline$\|$ & $6 \mathrm{X}$ & 4 menit & $45 \%$ & 5 set & 1 kali & $\begin{array}{c}\text { Skipping dengan } \\
\text { variasi }\end{array}$ \\
\hline
\end{tabular}




\section{Hasil Observasi dan Evaluasi Siklus I}

Kegiatan observasi dilakukan oleh observer yaitu teman sejawat dalam penelitian ini. Adapun variable yang diobservasi dengan menggunakan instrumen berupa lembar observasi yang mengukur kualitas tentang : (1) Kesegaran Jasmani(body health), (2) Kelincahan(aqility), (3) koordinasi (coordination), (4) Daya tahan (endurance), dan (5) kecepatan (speed). Dengan menggunakan lembar observasi, hasil observasi siklus I Disajikan dalam tabel 3.

Tabel 3. Hasil observasi siklus I

\begin{tabular}{|c|c|c|c|c|c|c|c|c|c|c|}
\hline \multirow[t]{2}{*}{ Nama Siswa } & \multicolumn{6}{|c|}{ Aspek Yang Diobservasi } & \multicolumn{4}{|c|}{ Kemampuan } \\
\hline & 1 & 2 & 3 & 4 & 5 & $\Sigma$ & TM & CM & $\mathbf{M}$ & SM \\
\hline 1. M.Jasri & 1 & 1 & 1 & 1 & 1 & 5 & V & V & - & - \\
\hline 2. Syahrul & 2 & 3 & 2 & 2 & 2 & 11 & - & - & V & - \\
\hline 3. Diki & 1 & 1 & 1 & 1 & 1 & 5 & V & - & - & - \\
\hline 4. Pebrio & 2 & 2 & 2 & 3 & 3 & 12 & - & - & V & - \\
\hline 5. Fasgo & 2 & 2 & 1 & 2 & 1 & 8 & - & V & - & - \\
\hline 6. Hendrawandi & 2 & 2 & 1 & 2 & 1 & 8 & - & V & - & - \\
\hline 7. Niko & 2 & 2 & 2 & 2 & 2 & 10 & - & V & - & - \\
\hline 8. Miketison & 2 & 3 & 2 & 2 & 2 & 11 & - & - & V & - \\
\hline 9. Rendy & 2 & 2 & 2 & 1 & 1 & 8 & - & V & - & - \\
\hline 10. Roymula & 1 & 1 & 1 & 1 & 1 & 5 & V & - & - & - \\
\hline 11. Suryanto & 1 & 1 & 1 & 1 & 1 & 5 & $\mathrm{~V}$ & - & - & - \\
\hline & & $\Sigma$ & & & & & 4 & 4 & 3 & - \\
\hline & & $\mu$ & & & & & $36 \%$ & $36 \%$ & $28 \%$ & - \\
\hline
\end{tabular}

Untuk mengetahui penguasaan materi yang telah diberikan pada siswa, Pada akhir pertemuan diberikan evaluasi, hasil evaluasi belajar siswa pada siklus I adalah seperti disajikan pada tabel 4 .

Tabel 4. Hasil Belajar pada Siklus I

\begin{tabular}{|c|c|c|c|c|c|c|c|}
\hline \multirow[t]{2}{*}{ No } & \multirow[t]{2}{*}{ Nama } & \multicolumn{4}{|c|}{ Kompetensi yang dinilai } & \multirow{2}{*}{$\begin{array}{c}\text { Jumlah } \\
(a+b+c+d)\end{array}$} & \multirow{2}{*}{$\begin{array}{l}\text { Rata- } \\
\text { rata }\end{array}$} \\
\hline & & $\begin{array}{l}\text { Awalan } \\
\text { (a) }\end{array}$ & $\begin{array}{l}\text { Lompatan } \\
\text { (b) }\end{array}$ & $\begin{array}{l}\text { Pukulan } \\
\text { (c) }\end{array}$ & $\begin{array}{l}\text { Pendaratan } \\
\text { (d) }\end{array}$ & & \\
\hline 1. & M.jasri & 40 & 50 & 40 & 50 & 180 & 45 \\
\hline 2. & Syahrul & 60 & 60 & 70 & 70 & 260 & 65 \\
\hline 3. & Diki & 40 & 40 & 50 & 50 & 180 & 45 \\
\hline 4. & Pebrio & 70 & 60 & 70 & 60 & 260 & 65 \\
\hline 5. & Fasgo & 60 & 60 & 60 & 60 & 240 & 60 \\
\hline 6. & Hendra & 70 & 60 & 50 & 60 & 240 & 60 \\
\hline 7. & Niko & 50 & 60 & 60 & 60 & 230 & 57,5 \\
\hline 8. & Miketison & 70 & 60 & 70 & 60 & 260 & 65 \\
\hline 9. & Rendy & 60 & 60 & 70 & 70 & 260 & 65 \\
\hline & Roymula & 50 & 50 & 50 & 50 & 200 & 50 \\
\hline 11. & Suryanto & 50 & 60 & 40 & 40 & 190 & 47,5 \\
\hline \multicolumn{6}{|c|}{ Jumlah } & & 625 \\
\hline \multicolumn{6}{|c|}{ Rata-rata } & & 56,8 \\
\hline
\end{tabular}




\section{Analisis dan Refleksi Siklus I}

Jika tabel-tabel diatas dianalisa, maka nampak bahwa penerapan latihan skiping belum dapat meningkatkan spike siswa dalam permainan bola voly sesuai dengan target yang direncanakan. Baru 28\% siswa yang dinyatakan mampu , $36 \%$ siswa baru mencapai cukup mampu melakuan spike, sementara sisanya $36 \%$ dikatakan tidak mampu melakukan spike. Kemudian hasil belajar yang dicapai siswa kelas VI SD Negeri 197/IX Pematang Gajah baru mencapai rerata 56,8, sehingga hasil belajar siswa pada siklus I baru mencapai tingkat penguasaan kompetensi $56,8 \%$.

Dari hasil analisis di atas dapat dikemukakan bahwa hasil penelitian pada siklus I diperoleh kesimpulan bahwa: Proses pembelajaran siklus I dengan menggunakan latihan skping belum sepenuhnya dapat meningkatkan hasil belajar siswa yaitu spike dalam permainan bola volly. Adapun indikator yang dapat disimak antara lain :

1. Proses pembelajaran yang diukur melalui lembar observasi baru mencapai 28 $\%$ siswa dapat mencapai kategori mampu.

2.Dampak lanjutnya adalah nilai rerata hasil belajar pada siklus I baru mencapai nilai 56,8 , yang berarti bahwa rerata tingkat penguasaan kompetensi siswa pada siklus I baru mencapai $56,8 \%$, dengan kata lain apabila dihubungkan dengan kriteria keberhasilan, belum memenuhi kriteria yang telah di tetapkan. Hasil refleksi berupa rumusan yang akan dilaksanakankan pada siklus II adalah sebagai berikut :

1. Siswa terutama kelompok yang $28 \%$ yang masih termasuk dalam kategori belum mampu, 36\% siswa baru mencapai cukup mampu;perlu diberi stimulus yang khusus agar mereka lebih tertarik mengikuti pembelajaran. Disamping itu perlu diingatkan kembali agar siswa mempersiapkan diri lebih baik lagi dalam mengikuti proses pembelajaran.

2. Tujuan dan manfaat pembelajaran perlu dijelaskan dengan lugas, para siswa harus diyakinkan bahwa memahami tujuan dan manfaat pembelajaran adalah untuk kepentingan diri mereka dalam mengarah proses pembelajaran agar tercapainya kompetensi sebagai hasil pembelajaran.

3. Pemberian stimulus untuk merangsang ingatan terhadap materi pelajaran pertemuan sebelumnya. Perlu mengacu kepada hasil test yang mengukur perubahan tingkah laku yang ditetapkan dalam rencana pelaksanaan pembelajaran.

4. Umpan balik berupa penguatan dari respon atau unjuk kerja (tugas latihan) harus diberikan secara langsung sebelum proses pembelajaran siklus II dimulai, sehingga tingkat kepuasan siswa terhadap penguasaan bahan yang telah dipelajari dapat ditingkatkan.

5. Pada pelaksanaan pembelajaran siklus- II siswa perlu diberi stimulus berupa pertanyaan-pertanyaan yang bersumber dari luar bahan ajar atau materi yang diberikan, seperti dari lingkungan keluarga

6. Evaluasi yang dilakukan pada siklus II perlu disesuaikan dengan indikator kompetensi yang ingin dicapai dengan tingkat kesulitan dan daya beda yang sesuai dengan kemampuan siswa. 
Menurut hasil yang didapat pada observasi , evaluasi serta refleksi diatas, maka dilakukan revisi terhadap Siklus I. Revisi ini nantinya dilakukan pada siklus II dengan kegiatan sebagai berikut : pada siklus berikutnya yaitu siklus II siswa dibimbing untuk latihan skiping lebih banyak lagi yang berulang kali. Skiping diberi beban sedikit agar nantinya pada saat spike (smas) lompatan siswa akan lebih meningkat.

\section{Hasil Penelitian Siklus II}

Penelitian siklus Iljuga dilakukan sebanyak dua kali pertemuan yaitu tanggal 15dan 17 Januari 2019. Penelitian pada siklus II dibagi dalam 4 (empat) kegiatan yaitu : 1) Perencanaan, 2) Pelaksanaan tindakan, 3) Observasi dan evaluasi, dan 4) Analisis dan refleksi.

\section{Perencanan Tindakan Siklus II}

Perencanaan tindakan yang akan dilakukan pada siklus II meliputi kegiatan yang terdiri dari :

a) Membuat Rencana Pelaksanaan Pembelajaran (RPP)

b) Menyiapkan materi pembelajaran olahraga yaitu meningkatkan kemampuan spike dalam permainan bola volly dengan latihan skiping yang diberi beban sedikit.

c) Menyiapkan semua sarana pendukung pembelajaran seperti; bola, beban, dan skiping.

d) Mempersiapkan format instrumen/ alat observasi yang akan digunakan pada saat proses pembelajaran berlangsung

e) Mempersiapkan alat evaluasi untuk mengetahui penguasaan materi pembelajaran dan untuk melihat hasil belajar.

\section{Pelaksanaan Tindakan Siklus II}

Pelaksanaan pembelajaran pada siklus II sama halnya pelaksanaan pembelajaran pada siklus I, pelaksanakan pembelajaran dilakukan dua kali pertemuan dengan waktu 2 × 30' setiap pertemuan. Pada setiap pertemuan dilaksanakan evaluasi untuk mengetahui hasil belajar siswa setelah diberikan tindakan. Hasil penilaian akan dijadikan dasar bagi perbaikan-perbaikan kegiatan pembelajaran selanjutnya. Hal ini dilakukan untuk menunjang tercapainya siklus II dalam rangka peningkatan kemampuan spikeanak untuk permainan bola volly yang menggunakan latihan skiping.

Pelaksanaan pembelajaran sama halnya siklus I yaitu diawali dengan salam dan do'a, kemudian anak diajak kelapangan bola volly. Pada awal pembelajaran siswa mengadakan pemanasan yaitu dengan melakukan gerakan tubuh bagian atas terlebih dahulu yaitu kepala. Kepala menoleh kekiri-kenanan, kepala dimiringkan kekiri-kekanan dan menundukkan kebawah dan keatas berulang kali. Berikutnya siswa menggerakkan badan bagian tengah yaitu pergelangan tangan yang diputar dan dirundukkan keatas dan kebawah, kemudian tangan direntangkan didepan dada 
dan dibuka berulangkali. Khusus tangan banyak variasi gerakan yang dapat dilakukan. Bagian pinggang diputar kekiri dan kekanan dan sebaliknya. Terakhir tubuh bagian bawah yaitu kaki dan pergelangan kaki.

Program latihan (tabel 5) pada siklus II para siswa melakukan skiping yang diberi beban sedikit, latihan skiping dilakuka sebanyak enam kali dimana setiap kali melakukan menggunakan waktu 4 menit. Setiap pelaksanaan skiping diberikan waktu istirahat dua menit. Setelah seluruh siswa melakukan skiping, guru membawa siswa untuk melakukan latihan spike (smas) secara bergantian.

Tabel 5. Program Latihan Skiping Siklus II

\begin{tabular}{ccccccc}
\hline $\begin{array}{c}\text { Pertemuan } \\
\text { ke }\end{array}$ & repitisi & durasi & intensitas & Set latihan & frekuensi & Bentuk \\
\hline I & $7 \mathrm{X}$ & 5 menit & $50 \%$ & 5 set & 1 kali & $\begin{array}{c}\text { Skipping dengan beban } \\
\text { ringan }\end{array}$ \\
\hline$I$ & $7 \mathrm{X}$ & 4 menit & $60 \%$ & 6 set & 1 kali & $\begin{array}{c}\text { Skippingdengan beban } \\
\text { ringan }\end{array}$ \\
\hline
\end{tabular}

\section{Hasil Observasi dan Evaluasi Siklus II}

Pelaksanaan kegiatan observasi dilakukan oleh guru lain sebagai observer yaitu teman sejawat dalam penelitian ini. Adapun variabel yang diobservasi dengan menggunakan instrumen berupa lembar observasi yang mengukur kualitas tentang :

$1=$ Kesegaran Jasmani (body health),

$2=$ Kelincahan (aqility),

$3=$ koordinasi (coordination),

$4=$ Daya tahan (endurance),

$5=$ kecepatan (speed)

Dengan menggunakan lembar observasi, hasil observasi siklus II Disajikan dalam tabel 6.

Tabel 6. Hasil Observasi Siklus II

\begin{tabular}{|c|c|c|c|c|c|c|c|c|c|c|c|}
\hline \multirow[t]{2}{*}{ No } & \multirow[t]{2}{*}{ Nama Siswa } & \multicolumn{6}{|c|}{ Aspek Yang Diobservasi } & \multicolumn{4}{|c|}{ Kemampuan } \\
\hline & & 1 & 2 & 3 & 4 & 5 & $\Sigma$ & TM & CM & M & SM \\
\hline \multicolumn{2}{|c|}{ 1. M.jasri } & 2 & 2 & 2 & 1 & 1 & 8 & - & V & - & - \\
\hline \multicolumn{2}{|c|}{ 2. Syahrul } & 3 & 3 & 2 & 2 & 2 & 12 & - & - & V & - \\
\hline \multicolumn{2}{|c|}{ 3. Diki } & 2 & 2 & 1 & 2 & 2 & 9 & - & V & - & - \\
\hline \multicolumn{2}{|c|}{ 4. Pebrio } & 2 & 3 & 3 & 3 & 3 & 14 & - & - & V & - \\
\hline \multicolumn{2}{|c|}{ 5. Fasgo } & 3 & 2 & 2 & 3 & 2 & 12 & - & - & V & - \\
\hline \multicolumn{2}{|c|}{ 6. Hendra } & 2 & 2 & 2 & 2 & 1 & 9 & - & V & - & - \\
\hline \multicolumn{2}{|c|}{ 7. Niko } & 2 & 3 & 3 & 2 & 2 & 12 & - & - & V & - \\
\hline \multicolumn{2}{|c|}{ 8. Miketyson } & 3 & 3 & 2 & 2 & 2 & 12 & - & - & V & - \\
\hline \multicolumn{2}{|c|}{ 9. Rendy } & 3 & 3 & 3 & 2 & 2 & 13 & - & - & V & - \\
\hline \multicolumn{2}{|c|}{ 10. Roymula } & 2 & 2 & 2 & 2 & 1 & 9 & - & V & - & - \\
\hline \multicolumn{2}{|c|}{ 11. Suryanto } & 2 & 2 & 2 & 1 & 2 & 9 & - & V & - & - \\
\hline & $\Sigma$ & & & & & & & - & 5 & 6 & \\
\hline & $\mu$ & & & & & & & - & $45 \%$ & $55 \%$ & \\
\hline
\end{tabular}


Untuk mengetahui penguasaan materi yang telah diberikan pada siswa, Pada akhir pertemuan diberikan evaluasi, hasil evaluasi belajar siswa pada siklus II adalah seperti disajikan pada tabel 7 .

Tabel 7. Hasil belajar siklus II

\begin{tabular}{|c|c|c|c|c|c|c|c|}
\hline \multirow[t]{2}{*}{ No } & \multirow[t]{2}{*}{ Nama } & \multicolumn{4}{|c|}{ Kompetensi yang dinilai } & \multirow{2}{*}{$\begin{array}{c}\text { Jumlah } \\
(a+b+c+d)\end{array}$} & \multirow{2}{*}{$\begin{array}{l}\text { Rata- } \\
\text { rata }\end{array}$} \\
\hline & & $\begin{array}{l}\text { Awalan } \\
\text { (a) }\end{array}$ & $\begin{array}{l}\text { Lompatan } \\
\text { (b) }\end{array}$ & $\begin{array}{l}\text { Pukulan } \\
\text { (c) }\end{array}$ & $\begin{array}{l}\text { Pendaratan } \\
\text { (d) }\end{array}$ & & \\
\hline & M.jasri & 50 & 60 & 50 & 60 & 220 & 55 \\
\hline 2. & Syarul & 70 & 70 & 70 & 70 & 280 & 70 \\
\hline 3. & Diki & 50 & 50 & 60 & 60 & 220 & 55 \\
\hline 4. & Pebrio & 70 & 70 & 80 & 70 & 290 & 72,5 \\
\hline 5. & Fasgo & 70 & 70 & 70 & 70 & 280 & 70 \\
\hline 6. & Hendra & 70 & 70 & 60 & 70 & 270 & 67,5 \\
\hline 7. & Niko & 60 & 70 & 70 & 70 & 270 & 67,5 \\
\hline 8. & Miketison & 70 & 70 & 80 & 70 & 290 & 72,5 \\
\hline 9. & Rendy & 70 & 70 & 70 & 70 & 280 & 70 \\
\hline 10. & Roymula & 60 & 60 & 60 & 60 & 240 & 60 \\
\hline 11. & Suryanto & 60 & 60 & 60 & 60 & 240 & 60 \\
\hline \multicolumn{7}{|c|}{ Jumlah } & 720 \\
\hline \multicolumn{7}{|c|}{ Rata-rata } & 65,5 \\
\hline
\end{tabular}

\section{Analisis dan Refleksi Siklus II}

Bila tabel 7 dianalisa, maka terlihat bahwa penerapan latihan skiping dapat meningkatkan spike siswa dalam permainan bola voly, namun belum sesuai target yang telah direncanakan. Siswa yang cukup mampu menjadi $45 \%$ yang sebelumnya baru mencapai $36 \%$. Sementara siswa yang mampu melakukan spike meningkat menjadi $55 \%$ yang sebelumnya hanya $28 \%$. Hasil belajar siswa kelas VI SD Negeri 197/IX Pematang Gajah meningkat menjadi rerata $65,5 \%$ yang sebelumnya hasil belajar baru mencapai nilai rerata $56,8 \%$, terjadi peningkatan hasil belajar sebesar $8,7 \%$.

Dari hasil analisis di atas dapat dikemukakan bahwa hasil penelitian pada siklus II diperoleh kesimpulan bahwa : Proses pembelajaran siklus II dengan menggunakan latihan skping dapat meningkatkan hasil belajar siswa yaitu spike dalam permainan bola volly. Adapun indikator yang dapat disimak antara lain :

1. Proses pembelajaran yang diukur melalui lembar observasi meningkat menjadi $55 \%$ siswa yang mencapai kategori mampu.

2.Dampak lainnya adalah nilai rerata hasil belajar siswa meningkat dari sebelumnya yaitu rerata 65,5 . Dimana siklus sebelumnya nilai rerata hanya 56,8 . Terjadi peningkatan sebesar $8,7 \%$. Namun peningkatan keberhasilan ini belum memenuhi kriteria yang ditetapkan yaitu nilai rereta 70 . 
Hasil refleksi berupa rumusan yang akan dilaksanakankan pada siklus III adalah sebagai berikut :

1. Siswa yang tergolong dalam kelompok cukup mampu (45\%) diberi stimulus agar mereka lebih tertarik mengikuti pembelajaran. Disamping itu perlu diingatkan kembali agar siswa mempersiapkan diri lebih baik lagi dalam mengikuti proses pembelajaran.

2. Tujuan pembelajaran perlu dijelaskan dengan lugas dan jelas, agar para siswa harus meyakini manfaat pembelajaran adalah untuk kepentingan diri mereka dalam mengarah proses pembelajaran agar tercapainya kompetensi sebagai hasil pembelajaran.

3. Pemberian stimulus untuk merangsang ingatan terhadap materi pelajaran pertemuan sebelumnya. Perlu mengacu kepada hasil test yang mengukur perubahan tingkah laku yang ditetapkan dalam rencana pelaksanaan pembelajaran.

4. Umpan balik berupa penguatan dari respon atau unjuk kerja (tugas latihan) harus diberikan secara langsung sebelum proses pembelajaran siklus III dimulai, sehingga tingkat kepuasan siswa terhadap penguasaan bahan yang telah dipelajari dapat ditingkatkan.

5. Pada pelaksanaan pembelajaran siklus- III siswa perlu diberi stimulus berupa pertanyaan-pertanyaan yang bersumber dari luar bahan ajar atau materi yang diberikan, seperti dari lingkungan keluarga dan lingkungan sekolah.

6. Evaluasi yang dilakukan pada siklus III perlu disesuaikan dengan indikator kompetensi yang ingin dicapai dengan tingkat kesulitan dan daya beda yang sesuai dengan kemampuan siswa.

Dari hasil yang diperoleh pada observasi , evaluasi serta refleksi diatas, maka dilakukan revisi terhadap Siklus II. Revisi ini akan dilakukan pada siklus III dengan kegiatan sebagai berikut : pada siklus III siswa dibimbing untuk latihan skiping lebih gigih dan kosentrasi yang penuh. Beban skiping akan ditambah sedikit lagi.

\section{Hasil Penelitian Siklus III}

Penelitian siklus III dilakukan sebanyak dua kali pertemuan yaitu tanggal 27 dan 28 Februari 2019. Penelitian pada siklus III dibagi dalam 4 (empat) kegiatan yaitu : 1) Perencanaan, 2) Pelaksanaan tindakan, 3) Observasi dan evaluasi, dan 4) Analisis dan refleksi.

\section{Perencanan Tindakan Siklus III}

Perencanaan tindakan yang akan dilakukan pada siklus III yaitu:

a) Membuatrancangan pembelajaran yaitu RPP (Rencana Pelaksanaan Pembelajaran) 
b) Mempersiapkan materi yang akan dajarkan pada siklus III yaitu latihan skiping dengan diberi beban lebih dalam upaya peningkatkan kemampuan spike dalam permainan bola volly.

c) Menyiapkan semua sarana pendukung pembelajaran seperti; bola, beban, dan skiping.

d) Mempersiapkan format instrumen/ alat observasi yang akan digunakan pada saat proses pembelajaran berlangsung

e) Mempersiapkan alat evaluasi untuk mengetahui penguasaan materi pembelajaran dan untuk melihat hasil belajar.

\section{Pelaksanaan Tindakan Siklus III}

Pelaksanaan tindakan pembelajaran siklus III dilakukan sebanyak dua kali pertemuan dengan waktu $2 \times 30$ ' setiap pertemuan. Pada setiap pertemuan dilaksanakan evaluasi untuk mengetahui hasil belajar siswa setelah diberikan tindakan.

Pelaksanaan pembelajaran sama halnya siklus sebelumnya yaitu diawali dengan salam dan do'a, kemudian anak diajak kelapangan bola volly. Pada awal pembelajaran siswa mengadakan pemanasan yaitu dengan melakukan gerakan tubuh bagian atas terlebih dahulu yaitu kepala. Kepala menoleh kekiri-kenanan, kepala dimiringkan kekiri-kekanan dan menundukkan kebawah dan keatas berulang kali. Berikutnya siswa menggerakkan badan bagian tengah yaitu pergelangan tangan yang diputar dan dirundukkan keatas dan kebawah, kemudian tangan direntangkan didepan dada dan dibuka berulangkali. Khusus tangan banyak variasi gerakan yang dapat dilakukan. Bagian pinggang diputar kekiri dan kekanan dan sebaliknya. Terakhir tubuh bagian bawah yaitu kaki dan pergelangan kaki.

Program latihan (tabel 8) pada siklus III para siswa melakukan skiping yang diberi beban sedikit, latihan skiping dilakuka sebanyak enam kali dimana setiap kali melakukan menggunakan waktu 4 menit. Setiap pelaksanaan skiping diberikan waktu istirahat dua menit. Setelah seluruh siswa melakukan skiping, guru membawa siswa untuk melakukan latihan spike (smas) secara bergantian.

Tabel 8. Program Latihan Skiping Siklus III

\begin{tabular}{ccccccc}
\hline $\begin{array}{c}\text { Pertemuan } \\
\text { Ke }\end{array}$ & Repitisi & Durasi & Intensitas & Set Latihan & Frekuensi & Bentuk \\
\hline I & $8 \mathrm{X}$ & 5 menit & $60 \%$ & 6 set & 1 kali & $\begin{array}{c}\text { Skipping } \\
\text { dengan beban lebih }\end{array}$ \\
\hline II & $9 \mathrm{X}$ & 5 menit & $65 \%$ & 5 set & 1 kali & $\begin{array}{c}\text { Skipping dengan } \\
\text { beban lebih }\end{array}$ \\
\hline
\end{tabular}

\section{Hasil Observasi dan Evaluasi Siklus III}

Pelaksanaan kegiatan observasi dilakukan oleh guru lain sebagai observer yaitu teman sejawat dalam penelitian ini. Adapun variable yang diobservasi dengan menggunakan instrumen berupa lembar observasi yang mengukur kualitas tentang : $1=$ Kesegaran Jasmani (body health),

2 = Kelincahan (aqility),

$3=$ koordinasi (coordination), 
4 = Daya tahan (endurance),

$5=$ kecepatan (speed)

Setiap akhir pembelajaran siswa diberi evaluasi, hal ini untuk mengetahui penguasaan materi yang telah diberikan.

Tabel 9. Hasil Belajar Siklus III

\begin{tabular}{|c|c|c|c|c|c|c|c|}
\hline \multirow[t]{2}{*}{ No. } & \multirow[t]{2}{*}{ Nama } & \multicolumn{4}{|c|}{ Kompetensi yang dinilai } & \multirow{2}{*}{$\begin{array}{c}\text { Jumlah } \\
(a+b+c+d)\end{array}$} & \multirow{2}{*}{$\begin{array}{l}\text { Rata- } \\
\text { rata }\end{array}$} \\
\hline & & $\begin{array}{l}\text { Awalan } \\
\text { (a) }\end{array}$ & $\begin{array}{l}\text { Lompatan } \\
\text { (b) }\end{array}$ & $\begin{array}{l}\text { Pukulan } \\
\text { (c) }\end{array}$ & $\begin{array}{l}\text { Pendaratan } \\
\text { (d) }\end{array}$ & & \\
\hline 1. & M.jasri & 70 & 80 & 80 & 70 & 300 & 75 \\
\hline 2. & Syarul & 80 & 80 & 80 & 70 & 310 & 77,5 \\
\hline 3. & Diki & 70 & 70 & 80 & 80 & 300 & 75 \\
\hline 4. & Pebrio & 80 & 80 & 80 & 80 & 320 & 80 \\
\hline 5. & Fasgo & 80 & 80 & 80 & 80 & 320 & 80 \\
\hline 6. & Hendra & 80 & 80 & 70 & 80 & 310 & 77,5 \\
\hline 7. & Niko & 70 & 80 & 80 & 70 & 300 & 75 \\
\hline 8. & Miketison & 80 & 80 & 80 & 80 & 320 & 80 \\
\hline 9. & Rendy & 80 & 80 & 80 & 80 & 320 & 80 \\
\hline 10. & Roymula & 70 & 70 & 80 & 80 & 300 & 75 \\
\hline 11. & Suryanto & 70 & 80 & 80 & 80 & 310 & 77,5 \\
\hline \multicolumn{6}{|c|}{ Jumlah } & & 852,5 \\
\hline \multicolumn{6}{|c|}{ Rata-rata } & & 77,5 \\
\hline
\end{tabular}

\section{Analisis dan Refleksi Siklus III}

Hasil analisis tabel 9 dapat diketahui bahwa pada siklus III telah terjadi peningkatan siswa yang mencapai kemampuan melakukan spike. Siswa yang mampu mencapai $73 \%$, bahkan yang sangat mampu $17 \%$. Berdasarkan analisis hasil olah data yang disajikan pada tabel 9 , nampak bahwa hasil pembelajaran spike dalam permainan bola volly yang menggunakan latihan skiping pada siklus III meningkat menjadi rata-rata 77,5. dibanding dengan hasil belajar siklus II yang hanya mencapai 65,5 , berarti telah terjadi kenaikan hasil belajar pada siklus III sebesar $12 \%$.

Dari hasil analisis tersebut dapat disimpulkan bahwa hasil penelitian tindakan kelas dengan menggunakan latihan skiping dalam permainan bola, setelah siklus -III dapat dinyatakan" berhasil". Keberhasilan ini ditunjukkan oleh indikator sebagai berikut:

a. Siswa seluruhnya dinyatakan berhasil mencapai kategori mampu melakukan spike dalam permainan bola voly mencapai $73 \%$ bahkan $17 \%$ dalam kategori sangat mampu.

b. Hasil belajar siswa kelas VI SD Negeri 197/IX Pematang Gajah mencapai nilai rerata 77,5 , melebihi kriteria yang ditetapkan yaitu rerata 70 .

Dari indikator di atas maka, Hipotesis Tindakan yang diajukan dalam PTK ini yaitu " Dengan menggunakan latihan skiping dapat meningkatkan kemampuan spike

\section{Yeni Sefiantri}


dalam permainan bola volly pada siswa kelas VI SD Negeri 197/IX Pematang Gajah dengan nilai rerata 77,5". Dapat Diterima. Latihan skiping dapat meningkatkan keterampilan open smas pada permainan bola voli dan dapat digunakan sebagai salah satu jenis latihan untuk meningkatkan smas siswa (Kusuma et al., 2018). Kemampuan spike berhubungan juga dengan kekuatan otot dan koordinasi mata pada permainan bola voli (Nasution, 2015).

\section{KESIMPULAN}

Kesimpulan yang dapat diambil dalam penelitian tindakan kelas ini adalah dengan menggunakan latihan skiping dapat meningkatkan kemampuan melakukan spike dalam permainan bola voly. Saran yang dapat penulis paparkan disini adalah: (a) Buat sekolah yaitu diharapkan guru penjaskes dapat melakukan latihan skiping agar dapat meningkatkan prestasi permainan bola voli. (b) Latihan skiping baik dilakukan oleh setiap peserta didik yang tidak memerlukan biaya yang besar dan tempat yang khusus.

\section{DAFTAR PUSTAKA}

Amum Makmun, Subroto. (2001), Pendekatn Ketrampilan Takis Dalam Permainan Bolavoli, Direktorat Jendral Olahraga. DEPDIKNAS. Jakarta

Arikunto, Suharsimi.(2002). Prosedur Penelitian Suatu Pendekatan Praktik. Jakarta: Rineka Cipta.

Arsil Bapirman. (2000), Pembinaan Kondisi Fisik, Penjas FKIP. UNP.

Bambang Markijanto. (1990), Kamus Lengkap Bahasa Indonesia Masa Kini. Bandung: Terbit Terang.

DEPNAS, PPKJ. (2000), PedomN Dan Modul Pelatihan Kesehatan Olahraga Bagi Peltih Olahragawan Pelajar. Jakarta

Hidayat, Iman. (2005). Penelitian Pengajaran, Diklat, Bandung, PPS Universitas Pendidikan Indonesia.

http : // myblog famours. Com / manfaat-skipping-olahraga-skipping-lompt-tali

Hanief, Y. N., \& Sugito. (2015). Membentuk Gerak Dasar pada Siswa Sekolah melalui Permainan Tradisional. Jurnal Sportif, 1(1), 60-73.

Kusuma, W. A., Syafaruddin, S., \& Destriana, D. (2018). Latihan Skipping terhadap Peningkatan Keterampilan Open Smash pada Permainan Bola Voli. Altius: Jurnal IImu Olahraga Dan Kesehatan, 7(1). https://doi.org/https://doi.org/10.36706/altius.v7i1.8127

Nasution, N. S. (2015). Hubungan Kekuatan Otot Lengan Dan Percaya Diri Dengan Keterampilan Open Spike Pada Pembelajaran Permainan Bola Voli Atlet Pelatkab Bola Voli Putri Kabupaten Karawang. JUDIKA (Jurnal Pendidikan Unsika), 3(2).

PBVSI. (1995:59). Latihan Explosive Power, Jakarta, PP.PBPSI

Nurhasan. (1994). Tes Dan Pengukuran Pendidikan Olah Raga. Bandung FPOK. Rushall dan Pyke. (1990). Pendidikan Daya Tahan Kardiovaskuler. Jakarta 
Surachmad, (1985). Pengantar Penelitian Ilmiah, Dasar dan Teknik Reseach. Bandung: Tarsito.

Syarif, A. (2018). Meningkatkan Kemampuan Gerak Motorik Kasar dengan Menggunakan Permainan Tradisional Manyipet pada Siswa Laki-Laki Kelas V di SD Negeri 7 Bukit Tunggal. Jurnal MERETAS, 5(2), 179-189.

Wibowo, Y. G., \& Indrayana, B. (2019). Sport: A review of healthy lifestyle in the world. Indonesian Journal of Sport Science and Coaching, 1(1), 30-34.

Yusuf M, (2003). Aplikasi Statistik dalam Penelitian. Penjas FKIP Unigal Ciamis. 